\title{
Nikola Novaković
}

University of Applied Health Sciences, Zagreb, Croatia

nikola.novakovic@zvu.hr

\section{Carnivalesque humour in Ça, c'est Filarmo, Nic}

\section{Izvorni znanstveni rad / original research paper}

Primljeno / received 18. 6. 2018. Prihvaćeno / accepted 16. 11. 2018.

DOI: $10.21066 /$ carcl.libri.8.1.4

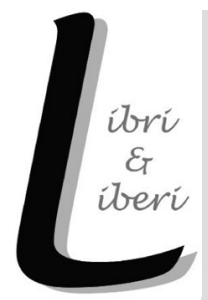

The article analyses the humour in Hermann Huppen and Morphée's series of comic books about a boy called Nick, with primary focus on the third issue, Ça, c'est Filarmo, Nic [That's Filarmo, Nick]. Drawing on Bakhtin's theory of the carnivalesque, the article identifies a variety of humorous devices, including wordplay, puns, quotations, unusual transformations, and mésalliances. Special attention is paid to the visual level of the comic book. Humour is located in visual metamorphoses, invisible "phantom" panels, and the incongruity between words and images. The article also addresses the comic book's intertextual ties with Little Nemo in Slumberland, a series of comic strips from the early $20^{\text {th }}$ century, and compares the way authority is represented and challenged in the two texts. The impossible spaces that Nick traverses within the chronotope of the road are examined as places that invert the usual hierarchies and relations, allowing Nick to experience a level of agency usually reserved for adults. The end of Nick's travels across the dreamscape is examined as both a departure and continuation of the pattern from Little Nemo, and as a logical conclusion of a temporary carnivalesque subversion of traditional structures that dominate the adult world.

Keywords: carnival, carnivalesque, humour, Bakhtin, chronotope of the road, comic book

The dream-world is the aquarium of night.

Victor Hugo, Toilers of the Sea (1866)

Hermann Huppen (1938), whose pen name is simply Hermann, is a Belgian comic book artist most famous for creating Jeremiah, a science fiction comic book series. Between 1981 and 1983, in collaboration with writer Philippe Vandooren (1935- 
2000), who is better known under his alias Morphée, Hermann published three comic books about the dreams of a ten-year-old boy called Nick. According to Hermann's official website, ${ }^{1}$ the audience did not respond favourably to the series, and it was soon cancelled. Each issue has a similar structure: a short introduction showing Nick before he falls asleep, which is followed by his fantastic dreams influenced by what he experienced before going to bed, finally ending with Nick waking up as a result of a climactic event in his dream. In the first issue, Hé, Nic! Tu rêves? [Hey, Nick! Are you dreaming?] (1981), Nick continually thwarts the plans of Captain Bang, who literally explodes whenever enraged, and whose main aim is to imprison Nick's animal friends in his zoo. The second issue, Bonnes nuits, Nic [Good night, Nick] (1982), contains Nick's misadventures in dreamland involving various means of transport, such as an oversized paper airplane and a toy train that grows to the size of a real one. In the third issue, Ça, c'est Filarmo, Nic [That's Filarmo, Nick] (1983), which is the primary focus of this article, Nick is seen in his bedroom painting his old tricycle, which he plans to give as a gift to the boy who lives next door. He then inadvertently spills some paint on his hardwood floor and is concerned about his parents' reaction. After falling asleep, Nick dreams that he is pedalling a tricycle, and soon encounters a man wearing a top hat, a three-piece suit, and a cape, also riding a tricycle (Fig. 1). We discover that this is Mr. Filarmo (whose name is a pun on the word "philharmonic"), who offers to help Nick clean up the stain, and then invites him to play in an orchestra that he plans to conduct. When it becomes apparent that Filarmo is still searching for musicians who will perform in his orchestra, Nick and Filarmo set out to find suitable candidates in dreamland.

The aim of this article is to provide a reading of the humorous dimension of the story in the third issue due to its more complex narrative and richness of intertextual allusions and humorous devices, while at the same time taking into consideration certain characters and scenes from the two preceding issues. This humorous component is examined within the framework of Mikhail Mikhailovich Bakhtin's ideas concerning the carnivalesque text and the chronotope, especially the chronotope of the road. This article aims to show that the carnivalesque nature of the comic book allows the child protagonist to embark on a quest that enables him to examine and question a number of adult authorities. The various humorous effects are also an outcome of the comic book's layered interaction with other texts, such as Little Nemo in Slumberland (1905-1927) by Winsor McCay, ${ }^{2}$ which serves as the most important intertext for Nic, providing it with both a visual and narrative background which the comic book both echoes and reconfigures in numerous interesting ways. This complex intertextual thread is further explored through the reading of the humorous effects achieved through quotations, references to music and musical knowledge, and allusions to art works.

\footnotetext{
$1<$ https://hermannhuppen.be/nic $>$

2 See Alexander Braun, Winsor McCay: The Complete Little Nemo 1905-1909 (2017) and Winsor McCay: The Complete Little Nemo 1910-1927 (2019).
} 

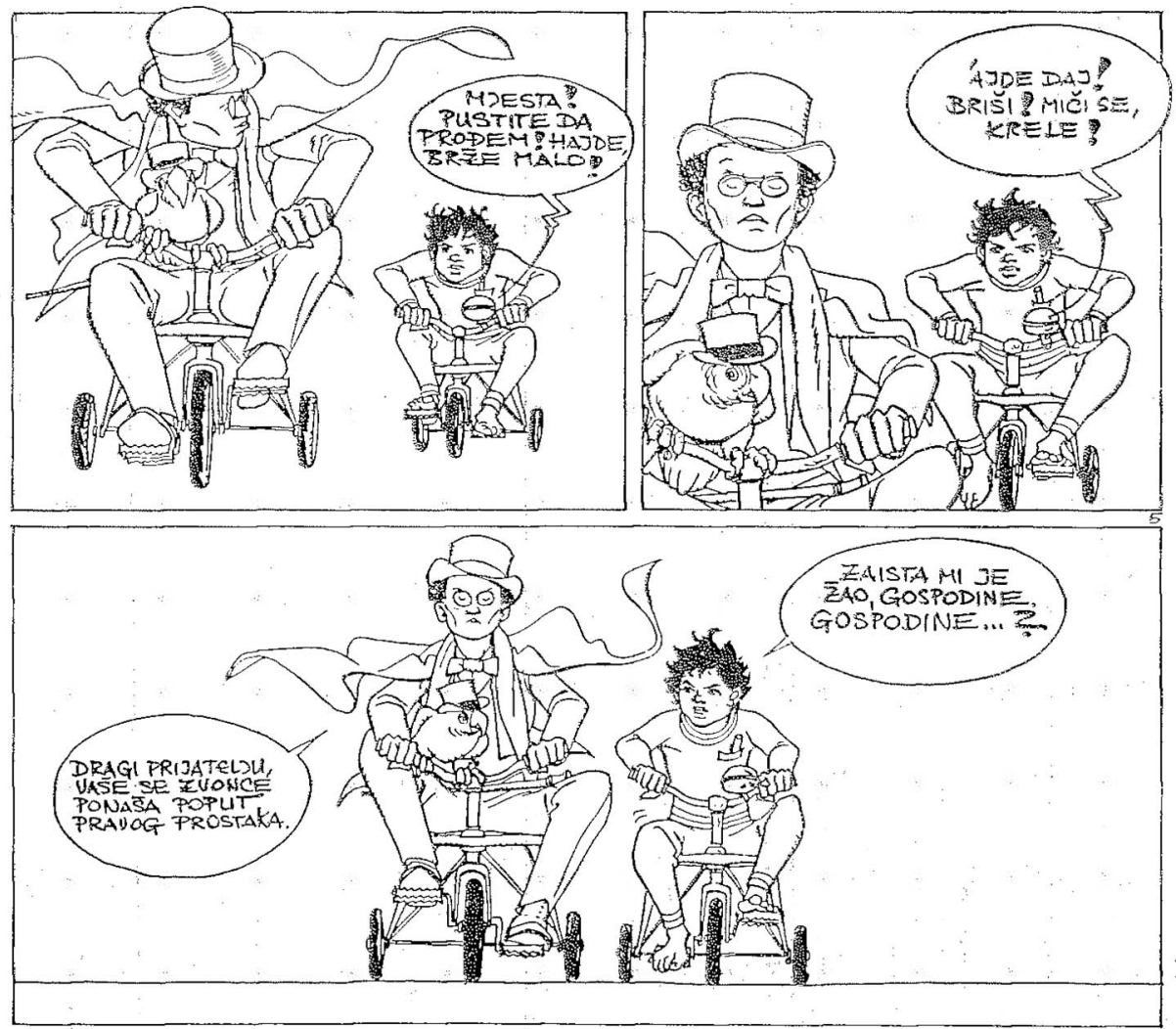

Fig. 1. Nick meeting Mr. Filarmo in the Croatian edition of Ça, c'est Filarmo, Nic (1994a: 19). ${ }^{3}$

Sl. 1. Nik susreće g. Filarma u hrvatskom izdanju stripa Ça, c'est Filarmo, Nic (1994a: 19).

The humour of Ça, c'est Filarmo, Nic is created both at the level of the comic book's structure and that of its story, including the visual component, which significantly contributes to the effectiveness of certain humorous devices. When discussing humour in any type of literature, we should first consider the various theoretical approaches to the difficult questions of what, when, or why something may be humorous, and what sort of effect humour may have on the text and its reader. There are generally thought to be three main theories or groups of theories of humour. Relief theory focuses on the effect that laughter has on us when we experience something humorous. This approach represents "the view that humorous laughter is a manifestation of the release of nervous excitement or emotional tension" (Bardon 2005: 468). According to the superiority

3 The Croatian edition was published in 1994 in Komiko, a children's magazine containing comic strips, puzzles, quizzes, games, crossword puzzles, and stories. An English translation was not available at the time of writing. 


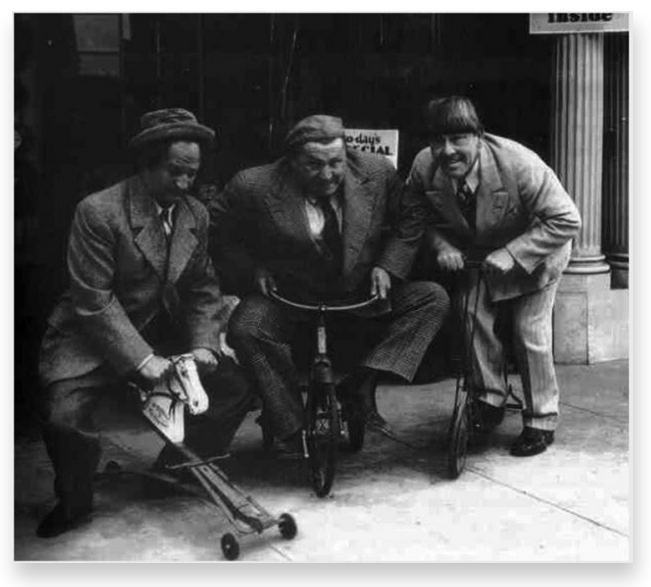

Fig. 2. The Three Stooges ${ }^{4}$

SI. 2. Trojica pripadnika vodviljske grupe The Three Stooges

theory, we laugh at others because we feel superior to them. In his work Laughter: An Essay on the Meaning of the Comic from 1900, Bergson considers laughter a sort of social corrective, since we laugh at those who show a rigidity of opinion, character, or behaviour in order to help them notice their own lack of flexibility and attempt to improve themselves (Bergson 2005: 43). One example of a character the reader may laugh at because they feel superior to him is the character of Captain Bang, who explodes out of anger whenever Nick interrupts his plans.

The incongruity theory, on the other hand, defines laughter as "an intellectual recognition of an absurd incongruity between conflicting ideas or experiences" (Bardon 2005: 465). This approach accounts for the humour we recognise in "[i]nappropriateness, paradox, dissimilarity", or the process in which "two incongruent components are somehow brought together, synthesized, made similar" (Raskin 1985: 31-32). To use an example from Hermann's comic, we may focus on the scene in which Nick meets Mr. Filarmo as they ride on their tricycles. In one panel they are seen riding separate vehicles, and in the very next one we see them sitting on a tandem tricycle, with Nick at the front and Mr. Filarmo in the back. The obvious metamorphosis or fusion of the two vehicles that has taken place in the invisible moment between the two panels is an example of what Benoît Peeters calls a phantom panel: an action which is implied by the juxtaposition of two panels (1998: 40). The incongruity created by the phantom panel further increases the already present comicality of two characters riding on tricycles obviously too small for them, with this element simultaneously establishing an intertextual link with other characters from texts and movies famous for employing

\footnotetext{
4 Image taken from The Three Stooges: An Illustrated History, From Amalgamated Morons to
} American Icons (2002) by Michael Fleming. 


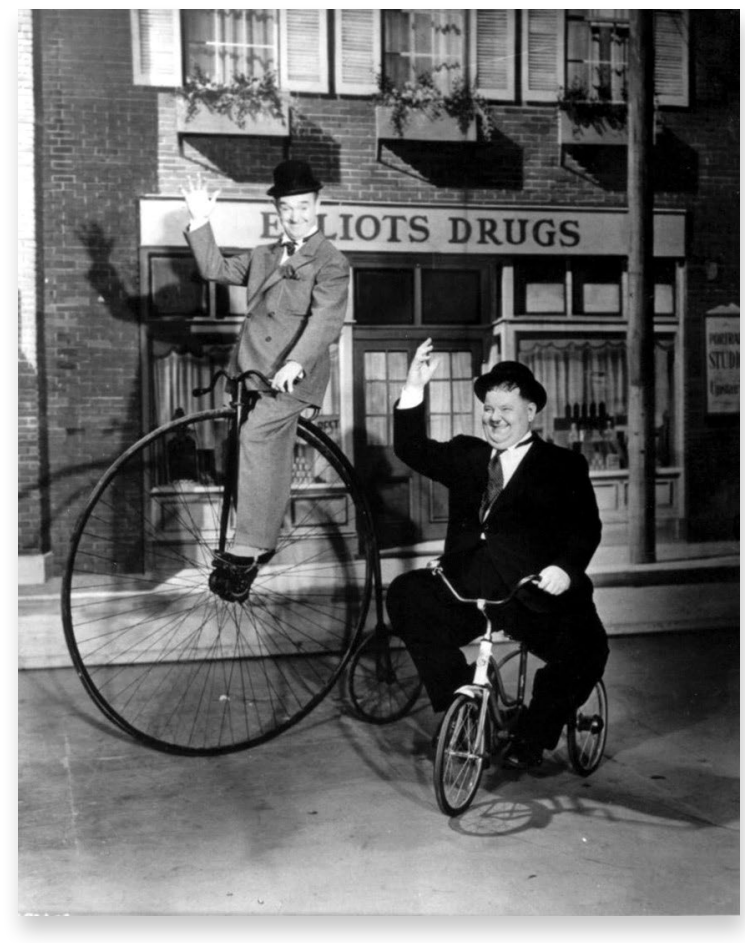

Fig. 3. Laurel and Hardy ${ }^{5}$

Sl. 3. Laurel i Hardy (u Hrvatskoj poznatiji kao Stanlio i Olio)

similar vehicles for comedic effect, such as The Three Stooges ${ }^{6}$ (Fig. 2) or Laurel and $\operatorname{Hardy}^{7}$ (Fig. 3).

\section{The carnival spirit and the chronotope of the road}

In our reading of Hermann and Morphée's comic book, we also employ Bakhtin's ideas on the carnivalesque and carnivalised writing, presented in his work Problems of Dostoevsky's Poetics (1999[1963]), in which the author identifies a carnivalesque text as one containing the characteristics of the carnival spirit such as inversion, parody, and discrowning. In a carnivalesque text, the world is turned upside-down, all the usual hierarchies are contested, and all the commonly accepted truths are tested and questioned: "[W]hat is suspended first of all is hierarchical structure and all the

5 Image taken from the website Pinterest $<$ https://www.pinterest.com/pin/375206212696516540/>.

6 The Three Stooges were an American vaudeville group active between 1922 and 1970 and famous for their 220 comedy films. The "stooges" were played by Moe Howard (1897-1975), Larry Fine (1902-1975), Shemp Howard (1895-1955), Curly Howard (1903-1952), Joe Besser (1907-1988), and Curly Joe DeRita (1909-1993).

7 Laurel and Hardy were a comedy duo active between the 1920s and 1940s, composed of Stan Laurel (1890-1965) and Oliver Hardy (1892-1957). Laurel and Hardy appeared in 170 comedy films. 
forms of terror, reverence, piety, and etiquette connected with it" (Bakhtin 1999: 123). This occurs simultaneously with the unification of opposites, or what Bakhtin calls the creation of carnivalistic mésalliances: "Carnival brings together, unifies, weds, and combines the sacred and the profane, the lofty with the low, the great with the insignificant, the wise with the stupid" (ibid.). As this paper aims to show, examples of the carnivalesque abound in Hermann's comic, but it is also important to notice that they occur within the framework of what is a road narrative or "adventure narrative", as Bakhtin, in his work The Dialogic Imagination (1981[1975]), refers to texts that maintain "the close link between the motif of meeting and the chronotope of the road ('the open road'), and of various types of meeting on the road" (Bakhtin 1981: 98). What is more, people who usually do not come into contact because they occupy different positions within certain hierarchies, or simply due to spatial distances, can be brought together as a result of accidental encounters that take place on the road. As Bakhtin says, "any contrast may crop up, the most various fates may collide and interweave with one another" (Bakhtin 1981: 243), which means that the chronotope of the road creates opportunities for carnivalistic mésalliances and encounters such as the central one between Nick and Mr. Filarmo.

The connection between children's literature and carnival has already received attention by critics. While examining "“subversive/transgressive' fiction", Julie Cross acknowledges the carnivalesque in children's literature, referring to John Stephens' view of carnival as "grounded in a playfulness which situates itself in positions of nonconformity" (Stephens 1992: 121) and adding that it "usually incorporates the overturning of existing social norms and adult authority" (Cross 2011: 40). Stephens distinguishes between texts that "offer the characters 'time-out' from the habitual constraints of society but incorporate a safe return to social normality" and texts that are "endemically subversive of such things as social authority, received paradigms of behaviour and morality, and major literary genres associated with children's literature" (Stephens 1992: 121). In a similar vein, Maria Nikolajeva claims that Bakhtin "applies the concept of carnival to literature, viewing it as a narrative device used to describe reality in a distorting mirror, in a state of temporary deviation from the existing order, as well as total freedom from societal restrictions" (Nikolajeva 2009: 10). Nikolajeva points out that "the concept of carnival is highly relevant for children's literature" since it allows child characters "to become strong, brave, rich, powerful, and independent on certain conditions and for a limited time", the most important condition being "the physical dislocation and the removal, temporary or permanent, of parental protection, allowing the child protagonist to have the freedom to explore the world and test the boundaries of independence" (10, italics in the original). In Ça, c'est Filarmo, Nic, the protagonist follows this narrative pattern by embarking on a quest in the land of his dreams, explores this fantastic landscape filled with carnivalesque adventures and characters and questions various authorities, until finally returning to the reality of his bedroom by waking up. He is, as Nikolajeva says, "brought back to the security of home and parental supervision", although the adventures retain their subversive effect 
by subjecting "adult normativity [...] to scrutiny" and revealing the arbitrary nature of certain rules imposed on children by adults (10).

As is frequently the case in carnivalesque children's literature (Pippi Longstocking by Astrid Lindgren, Lewis Carroll's Alice in Wonderland), child characters are empowered and given agency, with the characters themselves being highly independent and either opposed to adults or on an equal footing with them. This is what occurs in Nick's dream, with Nick travelling alongside Mr. Filarmo, but not as a child being led by an adult. Filarmo addresses Nick as his equal, criticises other adults in conversation with Nick, often asks Nick's permission to quote someone, offers to play music with Nick, and includes Nick in his orchestra as its first member.

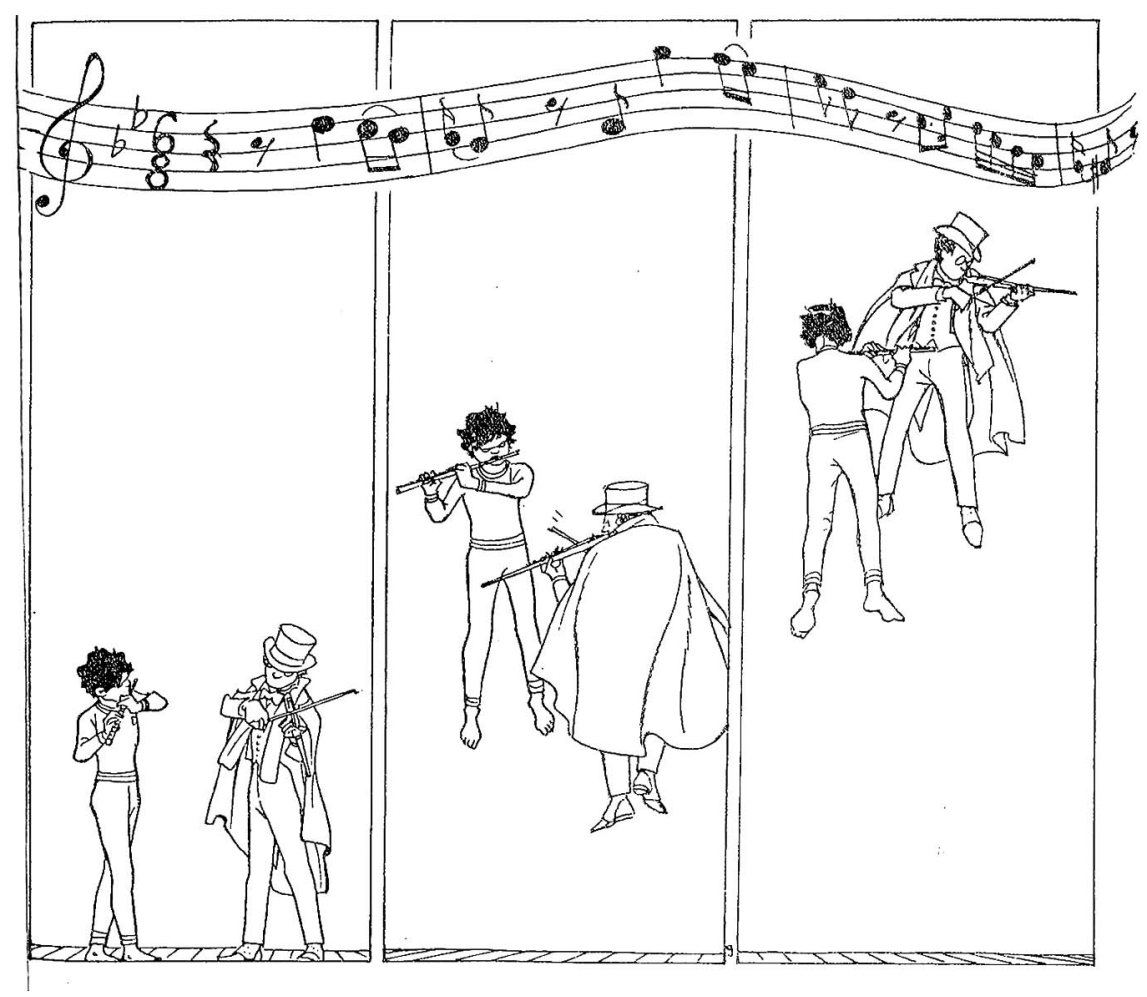

Fig. 4. Nick and Mr. Filarmo playing music together (Hermann and Morphée 1994a: 23). Sl. 4. Nik i g. Filarmo zajedno sviraju (Hermann i Morphée 1994a: 23).

In general, music acts as a complex element that brings Nick and Filarmo together, allows for the carnivalesque inversion of the adult-child relationship, and also functions as a catalyst for humour. In other words, it appears as both a serious and comical element, which aligns the text with the concept of spoudogeloios, the "serio-comical" or serious-smiling genres, which Bakhtin defines as genres in which "[p]recise and stable boundaries [...] are almost impossible for us to distinguish", 
and they are characterised by a rejection of stylistic unity, replacing it instead with a "deliberate multi-styled and heterovoiced nature [...] a multi-toned narration, the mixing of high and low, serious and comic" (Bakhtin 1999: 108). This is a characteristic immediately recognisable in Ça, c'est Filarmo, Nic. Nick and Mr. Filarmo share tender moments that reinforce the importance and advantages of listening and playing classical music, an unexpected element in a comic book populated by clowns, wordplay, talking animals, surreal inventions, and impossible spaces. For example, at the beginning of the story, while the two are still getting to know each other, Filarmo invites Nick to play the flute while he plays on his own instrument, which has magically transformed from a walking stick into a sort of violin. It is significant that Mr. Filarmo, who is obviously a more experienced musician (and physically resembles Gustav Mahler, but also the image of Aurèle Nicolet, a world-famous flute player, which hangs on the wall of Nick's bedroom), offers to follow Nick on his violin. The usual roles of master and apprentice are thus temporarily inverted, and as Nick and Filarmo begin to play, we observe them over three panels as they rise off the ground and levitate in the air (Fig. 4). However, the fantastic ability to levitate vanishes as soon as the musicians stop playing, and Nick and Mr. Filarmo tumble to the ground while talking about the qualities of music, but no injuries are sustained: they simply walk away, still absorbed in their conversation about music and dreaming. The comicality of the scene is not created solely by the incongruity between the previous serious tone and the sudden humorous element of a slapstick fall to the ground, but also by the incongruity between what the characters are saying ("Great music lifts the soul", ${ }^{8}$ Hermann and Morphée 1994a: 23) and the action of falling clumsily which happens in the panels. Additionally, Nick's response to $\mathrm{Mr}$. Filarmo's question "Were you planning on going to sleep immediately?" is another humorous element in this scene, since there is noticeable incongruity between the expected response and Nick's actual answer: “Oh no, Mr. Filarmo! I don't sleep when I dream" (Hermann and Morphée 1994a: 24). Of course, comical incongruity again takes place between the words and the image because the reader knows that Nick is sleeping as he dreams saying the above statement (although Nick's response may also be understood as a non-humorous statement about wakeful dreaming, such as dreaming about the future and the possibilities that it brings).

It is interesting to note that the scene outlined above takes place in a blank, white space, thus focusing the reader's attention on the characters and their words, with almost nothing to serve as visual background. Such a configuration of space emphasises the tension between the characters' comments about the effect and timelessness of music and their comical fall through the blank space. At the same time, this serves to align the scene with the type of chronotope of the road that Alexandra Ganser, Julia Pühringer, and Markus Rheindorf in their analysis of road movies define as lacking "a specific spatial realization", due to which "the centre of attention shifts to a metaphysical level,

8 All of the translations of Huppen and Morphée's works are mine and are based on the Croatian translation of the French originals. 
namely the characters' inner journey and their negotiations of personal [...] space while they have to overcome geographical as well as personal obstacles on their way" (2006: 6). As shown in the following sections of this article, Nick's inner journey is shaped and framed by a number of carnivalesque explorations of adult authorities, who often function more like brief, funny obstacles than reliable adults. This may be understood as a process of growing up, something that is hinted at in the very beginning by the fact that Nick is preparing to give away his tricycle (potentially understood as a symbol of his early childhood) and in the dream by the fact that Nick takes on the responsibility of helping Mr. Filarmo assemble his orchestra. And, as we have already noted, this configuration of the chronotope of the road as a setting or background "charges the road with the function of a meeting place for characters who would otherwise perhaps never meet", thus facilitating (in this case homosocial) bonding between characters and revelations regarding their "personalities, stories and backgrounds", while at the same time "a change of personal development can also be triggered off by a fellow travellertheir fates are intertwined, if only for a short while" (Ganser, Pühringer, and Rheindorf 2006: 6).

Nick's complex interactions with an adult, Mr. Filarmo, and their questioning of various authority figures that are analysed below position Nick somewhere between childhood and adulthood, a shifting state the ambiguity of which is further amplified by the hybrid places Nick visits: they are a blank "nowhere" (the featureless backgrounds in many of the panels) but can quickly shift and morph into a peculiar "somewhere" (a dreamlike version of Nick's bedroom; the impossibly large inside of Filarmo's umbrella; an Escher-like structure filled with stairways and balconies). All of this contributes to the significance of the places and spaces that Nick traverses on his journey, imbuing them with meaning similar to the one that Bakhtin assigns to the chronotope of the threshold. According to Bakhtin, the chronotope of threshold "can be combined with the motif of encounter, but its most fundamental instance is as the chronotope of crisis and break in a life", which is "connected with the breaking point of a life, the moment of crisis, the decision that changes a life" (Bakhtin 1981: 248). The comic book thus enacts an interaction between the chronotope of the road and that of the threshold, which is particularly relevant for children's literature. Ingrid Johnston explains, in her reading of contemporary Canadian literature for young adults (2012: 89):

Linked with the notion of limen in Latin, a threshold is a liminal space that refers to a transitory, in-between state or space, characterized by indeterminacy, ambiguity, hybridity, and the potential for subversion and change.

It is in such intimations of change from childhood into adulthood taking place on the road that Hermann and Morphée's comic book aligns itself with what Rachel Falconer, in her analysis of the importance of the chronotope of the threshold for the understanding of adolescent fiction, calls "fictions that focus on the edges of identity, the points of transition and rupture, and the places where we might, like microcosms of the greater world, break down and potentially assume new and hybrid identities" (qtd. in Johnston 2012: 89). 


\section{Intertextuality and humour}

The carnivalesque story of the comic book, certain of its visual elements, as well as the narrative structure of falling asleep, dreaming, and waking up all allude to another text of the same genre, a comic strip called Little Nemo in Slumberland by American cartoonist Winsor McCay. The second issue in the series about Nick even bears a dedication to McCay's work, and a poster of Little Nemo can be seen on the wall in Nick's bedroom (Fig. 5). The famous weekly comic strip that ran in newspapers between 1905 and 1926 featured a young boy called Nemo who dreams of fantastic adventures and then wakes up at the end of each strip, usually in a state of fear or agitation. The earlier comic strips about Little Nemo were mainly focused on stories about creatures who wished to fulfil the desire of Morpheus, the ruler of Slumberland, to have Little Nemo brought to his realm and act as his daughter's playmate. The various plots met with failure, sometimes due to Nemo's disregard of the rules of that realm or his lack of caution, and the dreams would end suddenly, the final panel always showing the same side-on view of Nemo's bed and him either in it, next to it, or falling from it. Over time, the stories became more varied, and Little Nemo dreamt of different scenarios, but the main structure of falling asleep, dreaming, and waking up remained intact.

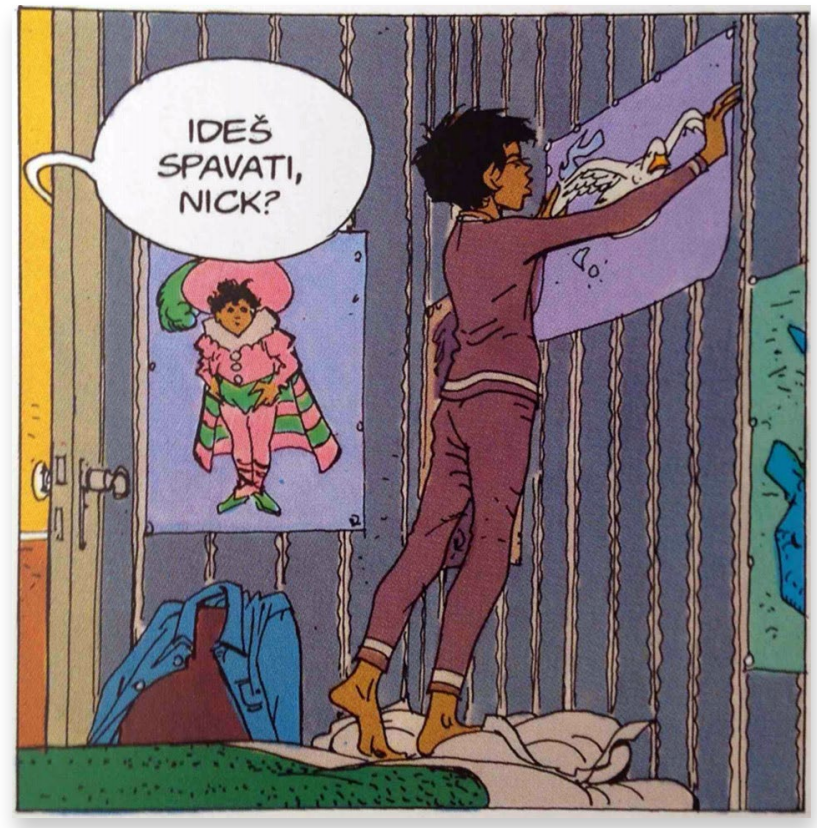

Fig. 5. The poster of Little Nemo (Hermann and Morphée 2003: 22).

SI. 5. Plakat koji prikazuje Maloga Nema (Hermann i Morphée 2003: 22). 

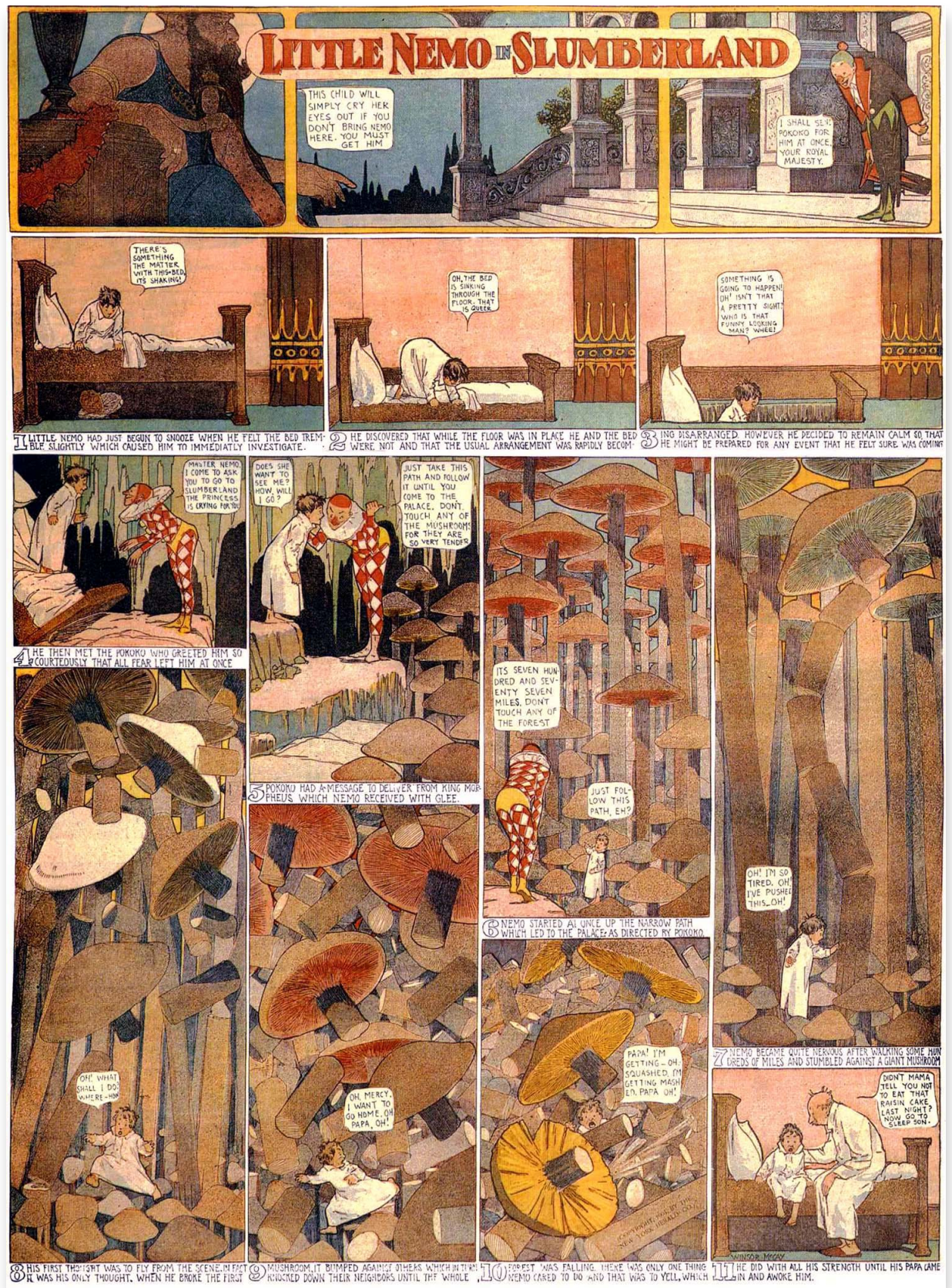

Fig. 6. Little Nemo in Slumberland (1905) ${ }^{9}$

SI. 6. Little Nemo in Slumberland [Mali Nemo u Drijemozemskoj] (1905)

9 Images of Little Nemo in Slumberland are in the public domain and are taken from the website $<$ www.comicstriplibrary.org $>$. 
Hermann's Nick visually resembles Nemo (both are Caucasian, black-haired boys dressed for bed, Nemo in a nightgown and Nick in pyjamas), although Nick appears to be several years older. Both boys fall asleep at the beginning of each comic strip, dream about fantastic or surreal events, and then wake up, after which the story or chapter ends. The final element mentioned here is the moment that represents perhaps the most striking resemblance between the two texts, since the abrupt break between the end of the dream and the final panel showing the now awake Nick closely mirrors the cut between the dream and reality in Little Nemo. While the perspective in the final panel in the comic books about Nick is never identical, the two boys' reactions upon waking up are sometimes similarly humorous because of the incongruity between the boys' reaction and their present context. In the final panels they are awake but occasionally still reacting to some terrifying event by screaming or pleading for help, and their bodies are often positioned in a way that mirrors their positions from the panel immediately preceding the final one. For example, in a strip from 1905, Little Nemo's screaming face, almost obscured by giant mushrooms that topple onto him, is repeated in the final panel (Fig. 6), in which he is still screaming while sitting up awake in his bed; at the end of the first chapter of Good Night, Nick, Nick's friends, the animals, fall on top of him from a destroyed paper airplane, causing him to wake up covered with pillows and blankets while crying out "They've all fallen onto me, mom!" (Hermann and Morphée 1994b: 11) (Fig. 7).

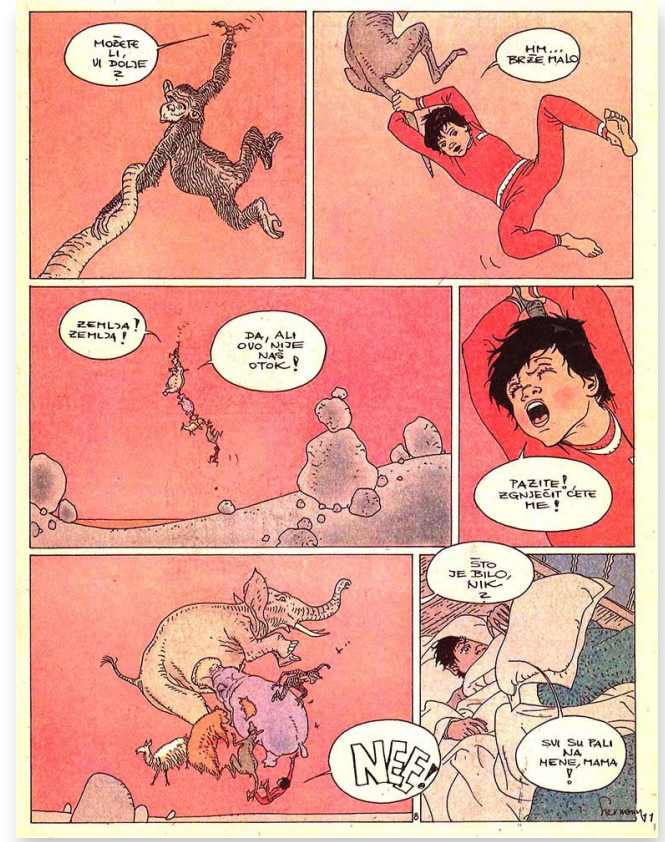

Fig. 7. Nick waking up (Hermann and Morphée 1994b: 11).

SI. 7. Nik se budi (Hermann i Morphée 1994b: 11). 
Another shared element is the presence of a wide variety of animals which can talk to Nick, express certain emotions such as fear or excitement, and are even able to use some objects intended for people, such as musical instruments. In both Little Nemo and Nic, the anthropomorphic animals function as a source of humour, often because they interrupt the action of the story with their unpredictable behaviour, which then leads to various misadventures. Apart from animals, both comic books also feature the adult members of the boys' families. Nemo's parents or grandparents are often seen standing or sitting on his bed in the final panel, frequently criticising him for eating a particular kind of food before going to bed because it may have caused his nightmares. On the other hand, Nick's parents are only heard speaking to him from another room before he goes to bed or after he wakes up from a dream, but they are similarly critical of his behaviour. The boys' misconduct or disregard of the rules is obviously not serious (Nemo supposedly indulges in food that his parents warned him against, while Nick stays up past his bedtime and lies to his parents about trivial things such as taking a bath), but such actions may be read as examples of these two child characters tentatively challenging the boundaries imposed by their parents. Of course, the frightening content of many of Little Nemo's dreams, the abrupt return to the present, and the panic with which Nemo seeks the protection of his family members may then be read as a child's departure from parental boundaries and a final panicked return to the protective circle of those very boundaries. Stephens claims that such carnivalesque explorations of boundaries in children's literature "offer the characters 'time-out' from the habitual constraints of society but incorporate a safe return to social normality" (1992: 121).

\section{Authority and humour}

The topic of questioning authority is reflected in the subversive nature of the humour of both texts. In an issue of Little Nemo from 1906 (Fig. 8), George Washington appears as a young boy in Nemo's dream, asking for his assistance in picking candied cherries from a tree. Washington first asks Nemo for a ladder, which Nemo provides, but when it becomes obvious that the ladder is too short, Washington suggests chopping down the tree. After Nemo fetches a hatchet and brings down the tree, the two boys begin eating the candied fruit, but the future president's angry father soon appears on the scene and demands that little George admit who committed the act. Claiming that he cannot tell a lie (which is a reference to the myth about Washington's honesty) and conveniently leaving out his own complicity in the deed, George confesses that it was Nemo who took down the tree. Nemo runs away, chased by Washington's father, and is then seen standing on his bed in the final panel, now fully awake and terrified. There are several incongruities at work in this comic strip. Firstly, there is the contrast between a serious story and a humorous one: in a playful and metafictional approach to the myth concerning an event from Washington's childhood, Little Nemo incorporates the "lofty" topic of Washington's honesty within the "low" framework of a comic book, bringing both stories and both boys to the same narrative level. Moreover, there is incongruity between what the reader expects from another retelling of the story about Washington 
and the cherry tree, and the actual outcome in the comic strip. In other words, instead of discovering a repetition of the myth about Washington's honesty, the reader encounters a version that plays with the perception of honesty as a tool for concealing complicity
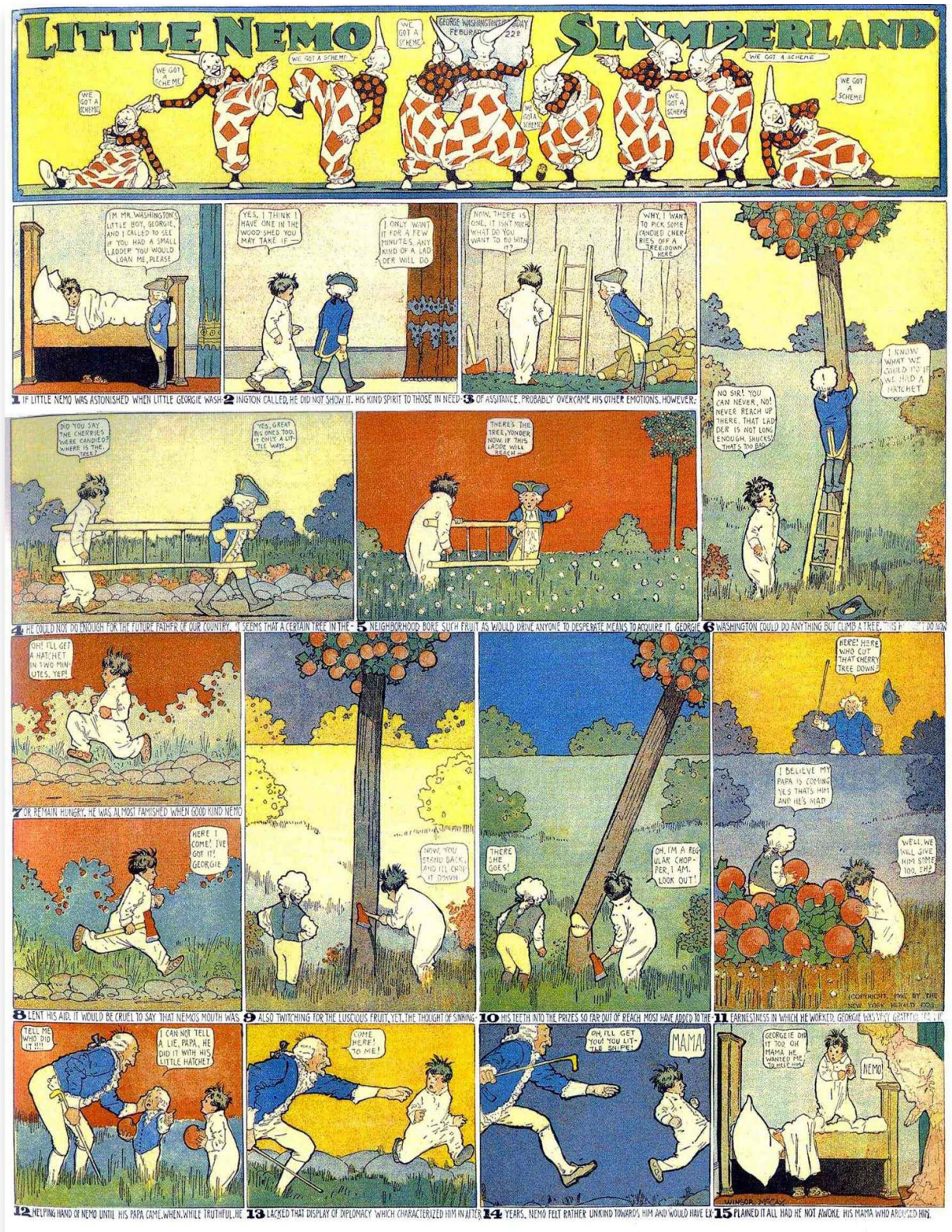

Fig. 8. Little Nemo in Slumberland (1906)

SI. 8. Little Nemo in Slumberland [Mali Nemo u Drijemozemskoj] (1906) 
and dishonesty. Humorous irony is therefore generated through the metafictional reworking of the myth, and the story about the advantages of always telling the truth turns this quality into a curse for Nemo: instead of leading to the famous scene of a father joyously celebrating his son's character, the comic strip erupts into a chase reminiscent of such scenes from slapstick movies.

The third issue in the series about Nick also contains a similarly playful approach to reader expectations, which leads to the carnivalistic questioning of hierarchies and authorities. We have already mentioned that Nick sometimes disobeys his parents or lies to them, and this questioning of authority continues in his dream. As Nick and Filarmo travel across Nick's dreamscape, they interview several candidates for Filarmo's orchestra. The first one is a clown, a classic comedic character, who produces from his pocket a metronome, claiming that anyone who talks about music is actually referring to rhythm. The clown knocks on the door of the metronome, asking the person within to open up. When they finally do, we realise that the occupant is a minuscule, grumpy old man dressed in pyjamas, whom the clown refers to as the "boss" and "Metronome". The tiny man flings open the doors and proceeds to berate the clown for disturbing him, claiming to be retired and expressing dissatisfaction with a lifetime spent keeping the beat for others. He refuses to continue doing so and proceeds to dress, pack his suitcase, and leave his home behind. There are a number of unexpected incongruities that the reader must navigate between in order to grasp the layered humour of this scene. Firstly, there is the carnivalesque mésalliance of a clown, who represents anarchic slapstick humour, being in charge of carrying around a precise object for keeping a regular rhythm. Secondly, the clown is a giant in comparison with the tiny person living in the metronome, yet the clown refers to him as "boss" and grows increasingly concerned as Metronome continues to criticise him and the circumstances of his own life. Furthermore, the size difference between the tiny man and the clown suggests a similarity between Metronome and children, while the comparatively large, concerned clown demonstrates a similarity with adults. However, while this comparison aligns the world of adults with the ridiculous figure of a clown, the humour is also directed at the departing Metronome, for in the enormous blank world of Nick's dream, his tiny, rebelling figure appears swamped by the negative space of the panel. Although he is attempting to leave behind the clown and his position in life, Metronome appears small and fragile, and we see in the next panel that the clown continues to follow him, still towering over him with his protective bulk.

We may therefore read the scene as a depiction of the complex relationship between adults and children (especially those on the threshold of adolescence, like Nick), which involves a struggle between dependence and independence, resistance and parental care. This relationship is further complicated when Nick and Filarmo encounter the next candidate for Filarmo's orchestra, an army general who offers the services of his military marching band. When the general mocks Nick and Filarmo for lacking bravery, the reader may initially be encouraged to accept the general's authority on the topic due to his profession. However, the visual representation of the general creates 
a humorous effect, since he is shown wearing an incredible number of medals and decorations that cover both sides of his chest, reaching down almost to his waist, which may encourage the reader to question the general's authority. This incongruity between rejection and acceptance of authority is a direct result of the humorous incongruity between the general's words and demeanour and his appearance. The incredible number of medals may attest to the general's bravery but may also be understood as a parody of his inflated ego, especially if the reader notices that among all the medals there is what appears to be a pacifier. This tiny detail, aligned with the world of very young children, humorously clashes with the surrounding signifiers of the adult world of war and bravery, thereby mocking the general's self-serious attitude.

The incongruity is further increased by the military band's performance. As the band begins to play, the general proceeds to sing about a certain woman, but the very next panel interrupts the performance and shows all the soldiers with lowered instruments and raised bottles, from which they appear to be drinking alcohol. The general then continues singing about the woman, describing how her colour changed from white to red, while Mr. Filarmo reveals to Nick that what the general is actually singing about is a type of bayonet from 1886. This intersection of Filarmo's reading of a woman as a metaphor for a weapon, presumably covered in the blood of an enemy, with the military band's drunken performance, reveals the serio-comical tone of the scene, but also of the metaphor itself, which is a grotesque conflation of the figure of a beautiful woman and the bloody acts associated with the use of a bayonet (which may invite phallic associations). As the song continues, the soldiers become so inebriated that they lose all ability to play their instruments (one drummer is seen wearing his drum on his head, and another one is sitting inside his) until they all finally fall asleep. Although the general and the soldiers began their song in a very orderly manner (in one panel they are seen marching as they play their instruments), their performance has ultimately invalidated them as candidates for Filarmo's orchestra. In fact, it has transformed them into a carnivalesque parody of authority, discipline, and hierarchy, since the effect of alcohol has erased the differences between the general and his soldiers, although we can notice that the general is the only one seen sleeping while standing above the prone soldiers, thus retaining an ironic hierarchical relation to those lower in rank than him (Fig. 9).

Having witnessed the military band's fall into a drunken stupor, Nick asks Mr. Filarmo the same question that he asked after he had seen the scene with Metronome: "Mr. Filarmo, was that a circus act?" Nick's confusion may be read as the result of the incongruity between what he expects from authority figures and how they actually behave in his dream. If this is Nick's way of tentatively questioning authority, Mr. Filarmo addresses the issue more openly when he responds by quoting Georges Clemenceau, who served as Prime Minister of France during the First World War: "Music is too serious a matter to entrust to military men". While the statement expresses a lack of confidence in the military, Filarmo has slightly modified the actual quote: "War is too serious a matter to entrust to military men" (Jackson 1946: 228). On the one hand, the 


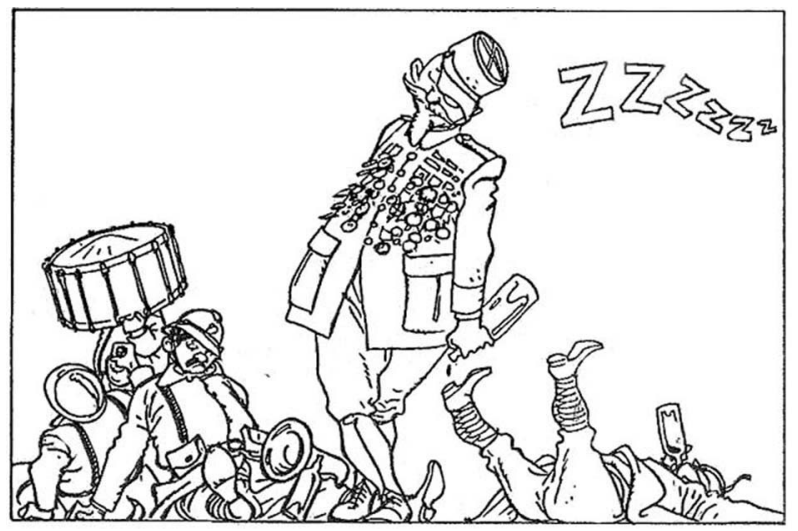

Fig. 9. The drunken military band (Huppen and Morphée 1994a: 31)

SI. 9. Pijani vojnički orkestar (Huppen i Morphée 1994a: 31)

altered quotation achieves its humour by mocking the abilities of army men, and on the other by playfully rewriting the original quotation. Of course, this second level requires the reader to recognise the modification in order for the humorous effect to be achieved. If we return to Bakhtin's analysis of the characteristics of the serio-comical genre, we recognise another of its elements in the comic book: "inserted genres - letters, found manuscripts, retold dialogues, parodies of the high genres, parodically reinterpreted citations" (Bakhtin 1999: 108). The above quotation is not the first such example in this comic book (the very first one is a line from a novel by Victor Hugo quoted at the beginning of Ça, c'est Filarmo, Nic, and is borrowed at the beginning of this article), nor is it the first example of playing with a quotation and thereby engaging the reader in the task of interpreting a text within a text. Before the scene with the metronome, Mr. Filarmo helps Nick clean up the stain on his floor by rolling it up like a carpet and dropping it into water through a hidden hatch in the floor of Nick's bedroom. As he does so, Filarmo quotes someone called Philippe André Novo: "My room is an open door to an unfamiliar world of which I am each night the wondering explorer" (1994a: 22). The reader may assume that Novo is the name of some novelist or poet, but in fact it is one of the aliases of Philippe Vandooren, aka Morphée, the writer of the comic books about Nick. While the first quotation we examined played with its content, in this example we discover a play on the text's source, which is a metatextual redirection of the reader's attention to the quotation itself and its author.

In the scene following the one with the drunken military band, Nick and Mr. Filarmo encounter the third candidate. They are approached by a very short-sighted and almost deaf firefighter, who also turns out to be a music critic (therefore inviting comparison with Hergé's Tournesol, an absent-minded, half-deaf professor). Two very different professions are thus combined within a single character who suffers from two physical problems that would seriously prevent him from performing either of 
his professions. Both the superiority and the incongruity theory of humour can be employed to explain why the reader may find the scene humorous. On the one hand, we laugh at the firefighter/critic in this scene because he seems to ignore his own problems with sight and hearing. For example, due to his impaired vision, the firefighter first addresses Nick and Filarmo as two ladies. Also, when Filarmo attempts to refuse the firefighter's offer of services by shouting ("I said goodbye!"), it becomes apparent that the firefighter has serious hearing problems because he assumes that Mr. Filarmo has accepted his offer, replying in a sentence that combines both his near blindness and deafness: "Excellent, madam! And when is the occasion?" (Hermann and Morphée 1994a: 33). He seems to be unaware of the severity of his problem, which is further emphasised when, in a self-serious manner reminiscent of the general, the firefighter/ critic states that he only works on "serious music," instead of genres such as musicals. A figure of authority who speaks from a position of apparent superiority about "serious music" thus becomes mocked by his own ignorance, with the reader drawing a parallel between the physical problems of the firefighter's vision and his professional shortsightedness in the field of criticism. The firefighter claims to be able to provide both rain and fair weather using his fire hose, which he directs upwards, thus creating a sort of artificial rain when the water falls back over him. Filarmo explains to Nick that the music critic is also a firefighter so that he can put out the flames of creativity, emphasising his attitude by quoting (this time correctly) Blaise Cendrars, a modernist novelist and poet: "Art criticism is as dumb as Esperanto" (Hermann and Morphée 1994a: 33; Jacobus Jr. 1979: 162).

Filarmo's interpretation of the surreal scene therefore serves as a questioning of another type of unreliable authority figure, this time a music critic, and Filarmo makes a point of listing other humorously flawed and untrustworthy critics, such as a film critic afraid of the dark or a literary critic who only reads what he writes himself. It is interesting to note that the firefighter/critic, upon incorrectly assuming that Filarmo has accepted his offer of service, makes a parody of a promise: "Do not worry: I will ruin everything to the best of my ability" (Hermann and Morphée 1994a: 33). The ridiculous statement certainly works to subvert the reader's expectations, but in the context of the ending of the comic book (which involves incredibly heavy rain interrupting a music performance), which is examined later, the firefighter's promise of ruining everything through his services may also be a concealed anticipation of a future event in the story.

\section{Humour and impossible spaces}

Following the two scenes described above, Filarmo encounters other candidates, including two performers of the one-man band variety, but also an entire host of different musicians, including an angel, a Scottish bagpipe player, another clown, a Viking, and a faun. Interestingly, one of the one-man band characters is a young woman, the only prominent female character in the story, who calls herself Noisemaker and challenges Filarmo on his ideas about music (Fig. 10). Noisemaker considers Filarmo overly rigid, since he rejects her offer of creating various kinds of noise, such 

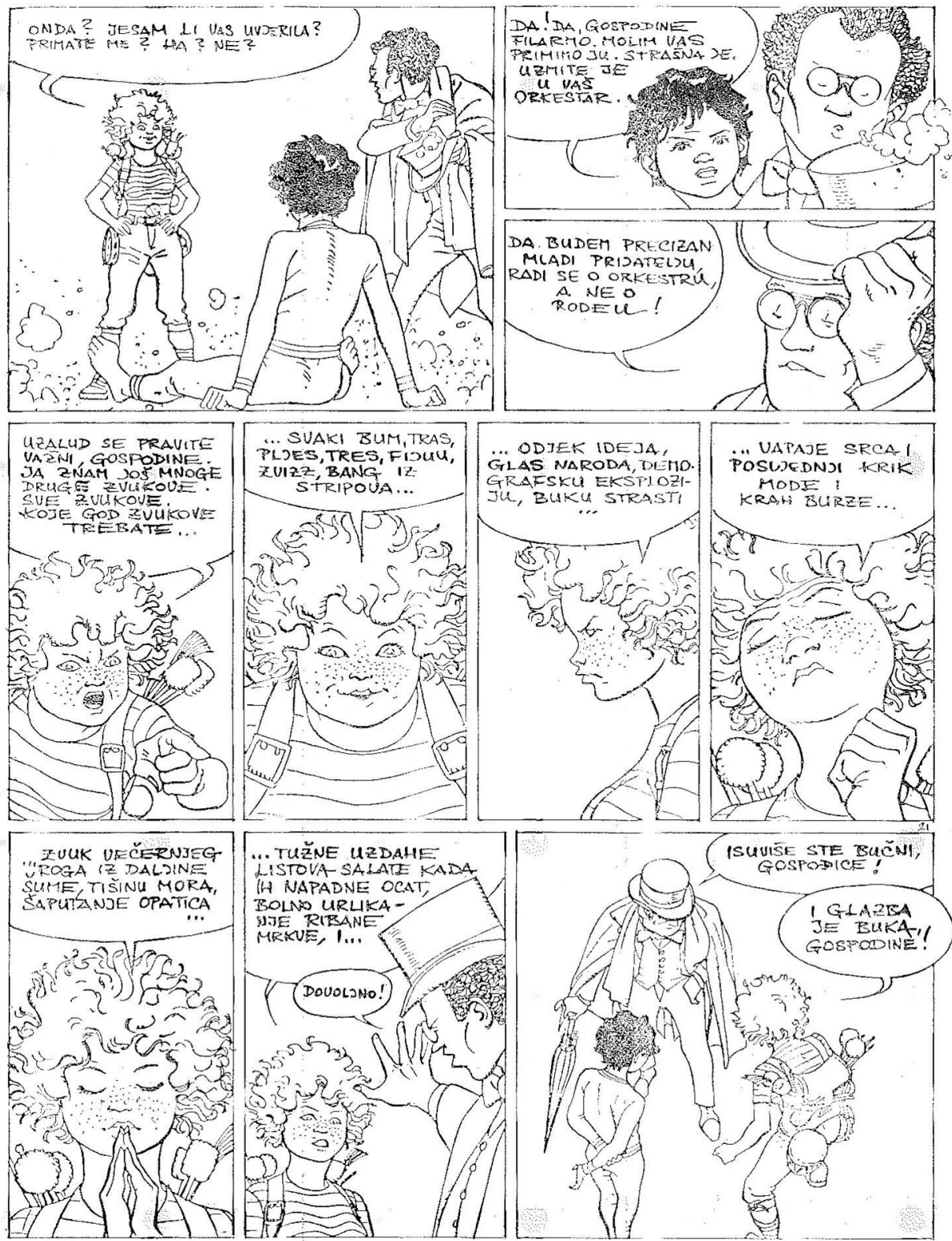

Fig. 10. Noisemaker confronting Mr. Filarmo (Hermann and Morphée, 1994a: 35).

Sl. 10. Bučna gospođica se suprotstavlja g. Filarmu (Hermann i Morphée, 1994a: 35).

as the echo of ideas, the noise of passion, the whispering of nuns, and the painful screams of a grated carrot. While Filarmo is dismissive of her abilities, Nick appears to be very interested, and urges Noisemaker to produce the sound of a grated carrot. 
By siding with the boisterous character of Noisemaker, Nick supports the injection of a disruptive carnivalesque element into Filarmo's understanding of music, briefly and playfully challenging his authority on the subject. It is therefore important to note that the scene in question positions all of the characters involved as humorous: Noisemaker for her carnivalesque disruption of the classical understanding of music and extreme focus on various noises, Filarmo for his elitism as perceived by Noisemaker, and Nick for his repeated insistence on hearing the sound of a grated carrot. The humour in this scene quickly switches from one target to another, inviting the reader to rapidly change their perspective. Carnivalesque texts often establish several simultaneous perspectives that "discourage simple identification with the subject position of one or more of the characters within the text", which means that the reader's identification with a character "may shift amongst such positions as empathy, delight, superiority, criticism, outrage, revulsion, and so on, and may even combine two or more in one response" (Stephens 1992: 124).

This scene of multidirectional humour, as well as the ones involving Metronome, the military band, and the firefighter, all take place in completely white, blank space with no background objects, but a sudden shift occurs at this point in the story, leading to the introduction of elaborately decorated and furnished spaces. In the "real" world of the comic book, lightning can be seen in the sky outside Nick's bedroom, and it is implied that loud thunder causes Nick to dream of himself falling through a sky filled with rain and lightning, which may remind us of the firefighter's use of the fire hose and his unusual promise. After Nick is rescued by Mr. Filarmo, the conductor's umbrella transforms into a vehicle that encloses them in a space that is much larger on the inside than on the outside. This impossible space appears to be decorated in the $18^{\text {th }}$ century style, with heavy drapery, a fireplace, high ceilings, an enormous chandelier, and ornate furniture. The space within the dream that was previously blank seems to have been replaced by a much more concrete and defined place dominated by a sense of order. However, the order of the characters' surroundings is another example of the visual element being in contradictory interaction with the words and action taking place in those surroundings. When Nick asks Filarmo about his plans for his orchestra, Filarmo replies that Nick's words remind him of his "Concert for a paperclip and other stationery". The title of the piece itself is a surreal parody of the usual names of musical compositions (the French word for "paperclip" is "trombone"), and Filarmo's story about the "Concert" is also very unusual, since it resembles a randomised succession of events. It is told over several panels, like an extended punchline, most of them showing Filarmo speaking. Among other things, Filarmo claims that the gaze of a Gypsy girl from Vladivostok set his manuscript on fire and that his composition was devoured by "green mice who survived the turbulent events of '68" (Hermann and Morphée 1994a: 42). We may assume this is a reference to the student revolts of 1968 , another example of confrontation with the authorities, but it can also be read as an intertextual allusion to the white mice that cause a lot of damage by constantly eating things in the second issue in the series. Additionally, the image of Filarmo, a character wearing a top hat 
and behaving eccentrically at tea time, recalls Lewis Carroll's Mad Hatter, thereby establishing a dialogue with a classic work of children's literature.

Filarmo's unpredictable story is at odds with the visual order of the impossible space within the umbrella, which is reinforced by Filarmo's eccentric behaviour. As Filarmo speaks, he pours tea into his top hat, adds sugar and stirs it, then picks up a china plate, dips it in the hot tea, and eats it. This takes place over seven panels, and when we finally see Nick again, the visual punchline is that he is huddled in his chair, looking anxious. Nick even says that he is slightly afraid of Filarmo, but it is at this moment that Filarmo breaks down because of his inability to find an orchestra and begins sobbing. The usual boundaries between an adult and a child are demolished, whereby Nick is allowed an insight into an adult's experience and display of grief and pain. Moreover, this moment challenges the traditional expectations regarding masculinity. The avoidance of the expression of emotions, commonly imposed on men by traditional gender roles governing the world of adults, is here subverted by Filarmo's behaviour. A similar effect is achieved earlier, by the female character of Noisemaker, whose depiction as a boisterous and assertive character undermines any expectation of an obedient or passive female character (thus reminding the reader of similar characters from the history of comic books, such as Hergé's Castafiore, Goscinny/Uderzo's chief's wife, and Lucy in Peanuts). Filarmo's display of emotions also involves a reversal of roles, with Filarmo in the position of the one in need of comfort (a role traditionally reserved for children) and Nick assuming the role of a person providing comfort (usually reserved for adults in this type of interaction). Nick performs this latter role by delivering a speech to encourage the sobbing conductor (Hermann and Morphée 1994a: 43):

Mr. Filarmo, the May wind will blow the uniform of the girl who worked in the cinema to Mexico, who will then light a fire in the editor's office with the help of green Gypsies, who will, even without cinema tickets, devour 68 mice from Vladivostok, but Jack London's flashlight will light up the surviving sheet music.

Nick's speech, in which he borrows and reorders certain points from Filarmo's story, further develops the mésalliance between ordered space and Filarmo's freewheeling story. Nick creates a narrative collage over several panels that is as surreal as Filarmo's original story, causing Filarmo to suddenly recuperate. In most of the other scenes in the story, Nick is usually an observer, but in this scene Nick takes over the narrative from an adult character and directs it back on track. It is important to notice that Nick's effective confrontation with adversity is performed through the use of a carnivalesque device of melding together various mutually incongruent parts of Filarmo's story, which reflects Filarmo's own playful approach to modifying quotations. While it was previously Filarmo who changed quotations or invented them outright, now it is Nick who uses Filarmo's approach, but in an even more unrestricted and creative manner. All of this allows us to read the environment of Nick's dream as a space that enables not only a questioning of authority, but also the attainment of child agency, with Nick's choices and decisions directly influencing events. As John McKenzie says of 
children's literature containing carnivalesque spaces, "[g]iven that it is the adult who writes, chooses and mediates children's literature, it is all the more salient that the carnivalesque, for a time, gives power to the child" (McKenzie 2005: 92).

Nick's reworking of Filarmo's story in his speech draws the reader's attention to the obvious intertextual relations between the words used by the two characters. Immediately after this scene, the text establishes an additional set of intertextual connections when Nick and Filarmo are visited by Nick's friends, the speaking animals from the previous two comic books in the series about Nick, who later offer to perform in Filarmo's orchestra. After Nick, Filarmo, and the animals hear someone playing Mozart in the building, they set out to find the source of the music, with the scene of the search depicted in only one panel. This involves another intertextual tie in the form of a visual quotation of the famous lithograph print Relativity (1953) by Maurits Cornelis Escher (1898-1972). While Escher's lithograph is populated by human-like figures performing everyday tasks (strolling, eating, carrying objects), in Hermann's reworking of the popular image the figures are replaced by a wide variety of domestic and wild animals, many of them talking at the same time about which direction they should go in, all of which transforms the scene into a parody of the original. The humour in this single panel is not solely the result of the blending of Escher's original with the animal characters from the comic book, but also stems from the mechanics of the original itself. On the one hand, there is humorous incongruity between the mundane tasks being performed by the figures in Escher's Relativity and the impossible space of stairs, alcoves, and balconies regulated by three sources of gravity, which the figures seem to ignore. On the other hand, the entire lithograph functions as a sort of joke at the reader's or viewer's expense, for any attempt at looking at the image is parodied by the inherent inability of the viewer to simultaneously comprehend all the conflicting parts of the image as a whole.

Escher's lithograph becomes a part of the comic book panel, and the characters a part of the parodied lithograph (Fig. 11). This intersection of the two texts is taken further when the characters finally reach the source of the music and come to a balcony overlooking an idyllic scene of nature in which four animals are performing a piece by Mozart. If we look closely at the bottom right of Escher's original, we will find there a scene of two people having a meal at a table set in some sort of garden. The view of nature from the balcony in the comic book is reminiscent of this detail from Escher's image, which is why we may assume that the characters in the comic book are still in Escher's maze, and the entire following scene takes place inside one of its details as an extension of the parodic reworking of the lithograph.

We may pause here briefly to address an obvious issue raised by this level of intertextual complexity encountered in a comic book for children. Since such a sophisticated text requires extensive knowledge of art works, music, and quotations, one may pose the question of whether this is truly a text that can be categorised as children's literature. Although some of the references may certainly be beyond the scope of a child's knowledge, they may encourage child readers to interpret them in 


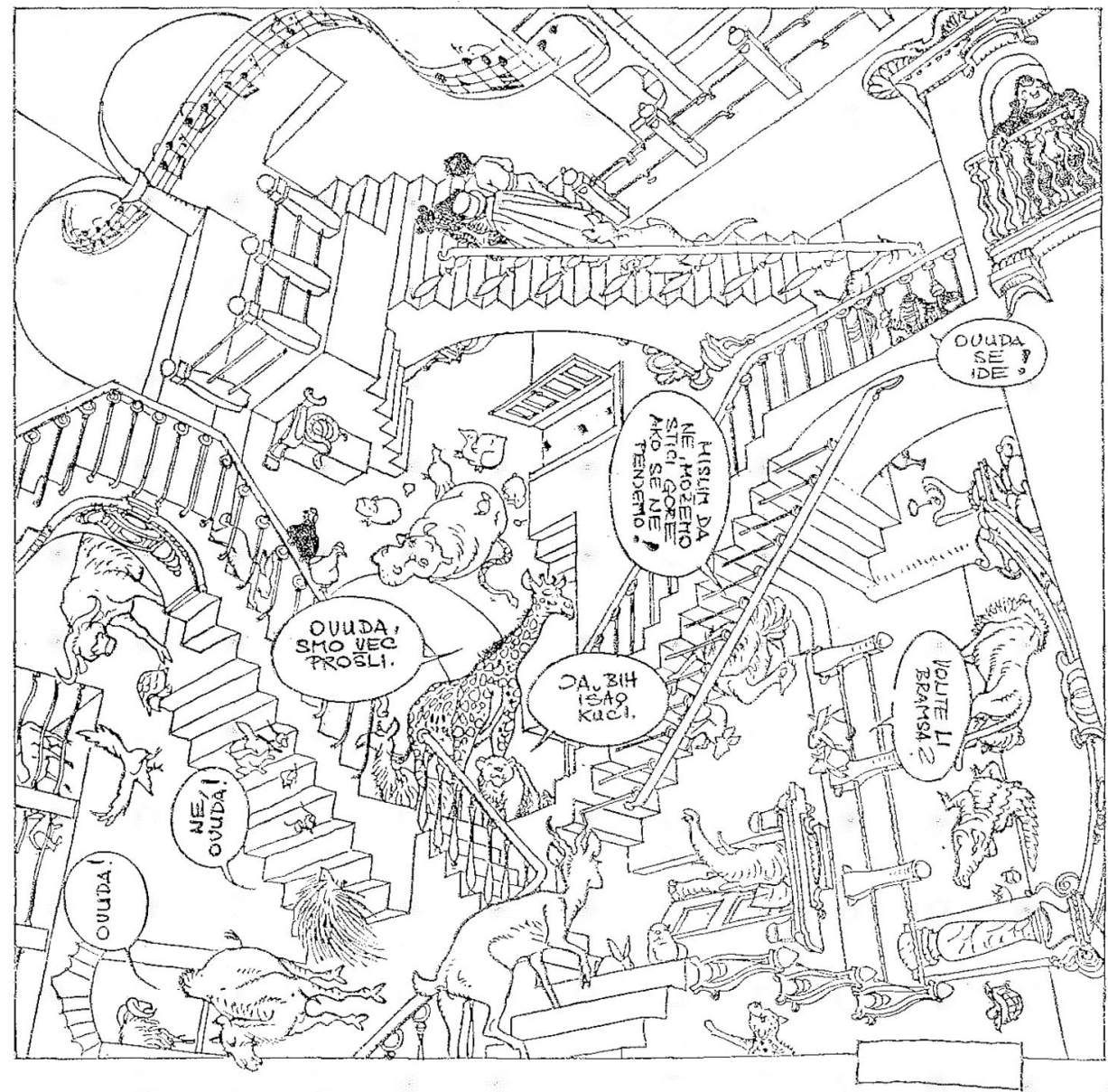

Fig. 11. An allusion to Escher's Relativity (Hermann and Morphée, 1994a: 46).

SI. 11. Aluzija na Escherovu litografiju Relativnost (Hermann i Morphée, 1994a: 46).

their own original ways and ultimately open new avenues for thinking and for understanding the text, the full scope of which the readers may uncover as they mature. On the other hand, as Sandra Beckett shows in her book Crossover Picturebooks: $A$ Genre for All Ages, works of children's literature containing complex allusions to the fine arts have "particular appeal with a crossover audience" (2012: 147) and address not only the child readers, but also the adults who read such literature to children. And while complex allusions to the arts can be enjoyed by children in their own way, Beckett also claims that many such references may even be overlooked by some adult readers, therefore posing a challenge to both groups of readers.

To return to the story of the comic book, after Filarmo accepts the animals' offer to perform in his orchestra, there are numerous comical scenes showing the animals choosing their instruments. In between these scenes, we find panels showing Mr. Filarmo 
becoming increasingly exasperated. The animals' carnivalesque misadventures occur in the background of the elaborate and regular architecture that constantly reminds us of Escher's impossible spaces, but also of the incongruities within his own works of art. In a documentary from 1999, Escher talks about his 1950 lithograph Contrast (Order and Chaos) (CINEMEDIA-NPS-RNTV): "[A]s a graphic artist about to make a print, you think: Let me balance this extreme regularity by making it the centre of a kind of chaos. Let me use it to illustrate the contrast between order and chaos". In Contrast (Order and Chaos), Escher placed a polyhedron in the centre of the image and surrounded it with broken and crumpled items, and it is the performance of classical music that takes on the role of the polyhedron, or "extreme regularity", in this scene and in this comic book in general. It is, of course, ironic that music acts as an element of regularity since its representation in the comic book simultaneously blurs the boundaries of media via intermedial references (whereby "formal features of other media like film and music are imitated by the means of graphic narratives" [Rippl and Etter 2013: 199]), therefore disrupting the strict regularity or uniformity of the text. To return to the plot of the comic book, just when it seems that the chaotic events involving animals that surround this "extreme regularity" will never end, Mr. Filarmo is surprised to discover an unexpected change: in a large single panel spread over two pages we see that all the animals have already taken their places in the orchestra and are waiting for their conductor. If we expected the number of humorously chaotic events to continue increasing indefinitely, then we may be surprised to find that order has been restored and the traditional value of the performance and enjoyment of classical music re-established in the unlikeliest of places: on a balcony located within the impossible space of Escher's lithograph, which has been parodically reimagined inside the impossibly enormous space of Filarmo's umbrella.

However, just when Filarmo is about to start conducting, rain begins to fall, and water rises almost immediately, flooding the balcony and the entire building. The comical tone is maintained by the statements made by some of the animals as the water reaches up to their necks: "What should we play?" "Water Music by George Friedrich" (Hermann and Morphée 1994a: 58). The final punchline is delivered if we remember the firefighter's promise to ruin everything to the best of his abilities, although it remains unclear whether or not this incredibly heavy rain is actually his work. As Nick swims, suddenly alone and looking for a way out of the water, he notices the same hatch that Filarmo opened in the floor of his bedroom at the beginning of the dream in order to throw away the rolled-up stain. Nick climbs up through it and finds himself back in his bedroom, looking down on himself as he sleeps. He attempts to wake up his sleeping self, afraid that he will drown in the rising water, and it becomes difficult to distinguish which Nick is real and which one is the dream version, or whether they are both dream versions or doppelgängers imagined by the real, unseen Nick dreaming the entire scene. Nick then wakes up in his bed, but in this reworking of the classic denouement of Little Nemo the expected punchline in the form of a comically surprised Nick seen in his bed, accompanied by a comment made by one of Nick's parents, has been replaced 
by Nick's ambiguous gaze seen through a rain-washed windowpane. In this ending, Nick is alone, we cannot hear his parents, and even the reader has left his room and can barely make out Nick's silhouette through a window obscured by heavy rain. In a complete departure from the expected ending, the final panel no longer shows us Nick, but only his house, now surrounded by more modern buildings with glass facades, and above all this we can see the rain falling and dense clouds towering over the city. While this ending may at first strike us as melancholic, we may consider it ambiguous because the return to the protection of the room provides reassurance and protection from the heavy rain. Although such an ambivalent ending does not mirror the comical endings of Little Nemo, it does continue the motif of postponed fulfilment of desire. This is a prominent feature of Little Nemo, for Nemo's wish to reach his goals or fulfil his desires in his dreams is postponed throughout numerous issues, and the same motif, represented by Filarmo's wish to conduct his orchestra and Nick's desire to help him, is maintained at the end of the comic book. By maintaining this motif, but avoiding the comical ending found in Little Nemo (and previous issues of the series about Nick), the comic book both subverts and continues the model inherited from McCay's comic strip.

As we have seen, the carnivalesque story inverts the usual roles in the child-adult relationship in such a way that it even grants Nick a significant level of agency on at least one occasion. Of course, as Nikolajeva points out, "the very idea of carnival presupposes a temporal limitation" and eventually the child "who has been allowed to leave the security of home and experience breath-taking adventures, is taken back, and the established order is restored" (Nikolajeva 2000: 7). This re-establishment of order is performed by Nick waking up from his dream, and although this returns the protagonist to the world controlled by the usual structures and hierarchies, the carnivalesque play is not mere indulgence in fantasy and entertainment but may be understood as "a rehearsal of a future moral and psychological transformation" (Nikolajeva 2000: 137). McKenzie shares a similar view, claiming that "[t]he carnivalesque challenges children to think about the social order through the reversal of roles, and in the closure brought about by the ending of the carnival, an increased awareness of the social nature of being-in-the-world" (McKenzie 2005: 91).

\section{Conclusion}

Humour plays an important role in Hermann and Morphée's comic book, appearing at the visual, structural, and textual levels in the form of various examples of wordplay, puns, quotations, phantom panels, the humorous interaction of words and images, unusual transformations, mésalliances, and intertextual ties. With regard to the theories of humour outlined in the introduction, it has been shown that the superiority theory can account for several examples of the humour we have discussed. This is most prominent in the case of various self-serious adult characters (the general, Metronome, the firefighter/critic) whose ignorance, inflexibility, and unreliability render them ridiculous and allow us to laugh at them alongside the main characters. On the other hand, the approach offered by the incongruity theory allows for a better 
understanding of numerous discrepancies between the expected and observed images, characterisations, expressions, situations, reactions, and other elements of structure and story. The humorous effect engendered by such instances of incongruity also involves an intricate web of allusions, references, and quotations which allows us to read this comic book as a carnivalesque text whose multidirectional laughter questions traditional authority, gender roles, and other existing norms and hierarchies, while also occasionally directing the humour at the main characters and thereby provoking a more complex response from the reader. At the same time, it is a road narrative, and the humorous situations and meetings that occur in the course of the travels that the main character undertakes imbue him with a sort of power and agency that is usually reserved for adults. However, while the central dream-journey challenges authority figures and the structures that dominate the adult world, with the motif of a return to the protection of the family home, the text re-establishes its intertextual links with Little Nemo, returning the protagonist to the established order of his reality and bringing the carnival of his dream to an end.

\section{Acknowledgments}

We are grateful to Yves Hermann for giving Nikola Novaković permission to include images from the comic book Ça, c'est Filarmo, Nic by Hermann Huppen and Morphée, originally published in 1983, in his paper in both printed and electronic versions of this issue of Libri \& Liberi. All the other images included in this paper are in the public domain.

\section{References}

\section{Primary sources}

Huppen, Hermann \& Morphée. 1981. Hé, Nic! Tu rêves? Marcinelle-Charleroi: Dupuis. Huppen, Hermann \& Morphée. 1982. Bonnes nuits, Nic. Bruxelles: Dupuis, DL. Huppen, Hermann \& Morphée. 1983. Ça, c'est Filarmo, Nic. Paris: Dupuis. Huppen, Hermann \& Morphée. 1994a. Nik i gospodin Filarmo [Ça, c'est Filarmo, Nic]. Komiko, strip magazin za mlade 1: 14-60. Transl. Irena Zappia. Rijeka: Novi list.

Huppen, Hermann \& Morphée. 1994b. Laku noć, Nik [Bonnes nuits, Nic]. Komiko, strip magazin za mlade 2: 4-11, 13-18, 83-85, 88-97. Transl. Irena Zappia. Rijeka: Novi list.

Huppen, Hermann \& Morphée. 2003. Hej, Nik, sanjaš li? [Hé, Nic! Tu rêves?] Transl. Milena Benini. Zagreb: Strip-agent.

\section{Secondary sources}

Bakhtin, Mikhail Mikhailovich. 1981[1975]. The Dialogic Imagination: Four Essays. Transl. Caryl Emerson \& Michael Holquist. Austin: University of Texas Press.

Bakhtin, Mikhail Mikhailovich. 1999[1963]. Problems of Dostoevsky's Poetics. Ed. and transl. Caryl Emerson. Minneapolis and London: University of Minnesota Press.

Bardon, Adrian. 2005. The Philosophy of Humor. In Comedy: A Geographic and Historical Guide, Volume 2, ed. Maurice Charney, 462-476. Connecticut: Greenwood Press.

Beckett, Sandra L. 2012. Crossover Picturebooks: A Genre for All Ages. New York and London: Routledge. 
Bergson, Henri. 2005[1900]. Laughter: An Essay on the Meaning of the Comic. Transl. Cloudesley Brereton \& Fred Rothwell. London: Macmillan.

Braun, Alexander, ed. 2017. Winsor McCay: The Complete Little Nemo 1905-1909. Cologne: Taschen $\mathrm{GmbH}$.

Braun, Alexander, ed. 2019. Winsor McCay: The Complete Little Nemo 1910-1927. Cologne: Taschen GmbH.

Chavez, Zachary. n.d. Comic Strip Library. < https://www.comicstriplibrary.org/> (accessed 1 July 2018).

Cross, Julie. 2011. Humor in Contemporary Junior Literature. New York and London: Routledge.

CINEMEDIA-NPS-RNTV. 1999. M.C. Escher Documentary. <https://www.youtube.com/ watch? $\mathrm{v}=\mathrm{g} 4$ VAxilTRGs $>$ (accessed 18 July 2018).

Fleming, Michael. 2002. The Three Stooges: An Illustrated History, From Amalgamated Morons to American Icons. New York: Broadway Books.

Ganser, Alexandra, Julia Pühringer \& Markus Rheindorf. 2006. Bakhtin's Chronotope on the Road: Space, Time, and Place in Road Movies Since the 1970s. Facta universitatis 4 (1): 1-17.

Huppen, Hermann. Nic. n.d. <https://hermannhuppen.be/nic/> (accessed 1 July 2018).

Jacobus Jr, Everett F. 1979. Cendrars' Variegated Poetic Persona: Seduction and Authenticity in Prose of the Transsiberian and Nineteen Elastic Poems. Studies in $20^{\text {th }}$ Century Literature 3 (2): 153-171.

Johnston, Ingrid. 2012. The Chronotope of the Threshold in Contemporary Canadian Literature for Young Adults. Jeunesse: Young People, Texts, Cultures 4 (2): 139-149.

McKenzie, John. 2005. Bums, Poos and Wees: Carnivalesque Spaces in the Picture Books of Early Childhood. Or, Has Literature Gone to the Dogs? English Teaching: Practice and Critique 4 (1): 81-94.

Nikolajeva, Maria. 2000. From Mythic to Linear: Time in Children's Literature. London: The Children's Literature Association and The Scarecrow Press, Inc. Lanham, Md.

Nikolajeva, Maria. 2009. Power, Voice and Subjectivity in Literature for Young Readers. New York and London: Routledge.

Peeters, Benoît. 1998. Case, planche, récit: Comment lire une bande dessinée. Paris: Flammarion.

Pinterest. n.d. <https://www.pinterest.com/pin/375206212696516540/> (accessed 1 July 2018).

Raskin, Victor. 1985. Semantic Mechanisms of Humor. Dordrecht, Boston, and Lancaster: D. Reidel Publishing Company.

Rippl, Gabriele \& Lukas Etter. 2013. Intermediality, Transmediality, and Graphic Narrative. In From Comic Strips to Graphic Novels Contributions to the Theory and History of Graphic Narrative, ed. Daniel Stein \& Jan-Noël Thon, 191-217. Berlin/Boston: Walter de Gruyter GmbH.

Stephens, John. 1992. Language and Ideology in Children's Fiction. London: Longman.

\section{Nikola Novaković}

Zdravstveno veleučilište, Zagreb, Hrvatska

\section{Karnevaleskni humor u stripu Nik i gospodin Filarmo}

U radu se analizira humor u serijalu stripova Hermanna Huppena i Morphéea o dječaku Niku, a primarni je fokus na trećem dijelu, Ça, c'est Filarmo, Nic (Nik i gospodin Filarmo). 
Koristeći se Bahtinovom teorijom karnevalesknoga, članak ističe niz komičnih postupaka poput igre riječima, dosjetaka, citata, neobičnih transformacija te mezalijansa. Posebna je pažnja posvećena vizualnoj razini stripa. Humor se prepoznaje u vizualnim metamorfozama, nevidljivim fantomskim kadrovima te proturječnom prožimanju riječi i slika. Članak se također bavi intertekstualnim sponama sa stripom Little Nemo in Slumberland [Mali Nemo u Drijemozemskoj], serijalom stripova s početka dvadesetoga stoljeća, te uspoređuje način na koji se u obama tekstovima predstavlja i osporava autoritete. Nemogući prostori kojima Nik prolazi unutar kronotopa puta proučavaju se kao mjesta koja izvrću uobičajene hijerarhije i odnose, omogućavajući Niku da iskusi razinu djelovanja koja je inače rezervirana za odrasle. Svršetak Nikovih putovanja svijetom snova proučava se kao istovremen prekid i nastavak obrasca posuđenoga iz stripa Little Nemo, te kao logičan završetak privremene karnevaleskne subverzije tradicionalnih struktura koje dominiraju svijetom odraslih.

Ključne riječi: karneval, karnevaleskno, humor, Bahtin, kronotop puta, strip 